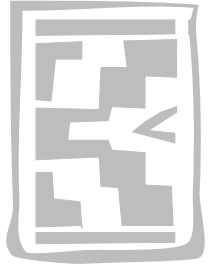

RESEARCH COMMUNICATION

\title{
Ticks (Acari: Ixodidae) collected from animals in three western, semi-arid nature reserves in South Africa
}

\author{
H. GOLEZARDY ${ }^{1}$ and I.G. HORAK ${ }^{2 *}$
}

\begin{abstract}
GOLEZARDY, H. \& HORAK, I.G. 2007. Ticks (Acari: Ixodidae) collected from animals in three western, semi-arid nature reserves in South Africa. Onderstepoort Journal of Veterinary Research, 74:81-85

The objective of this study was to make an inventory of the ixodid tick species infesting wild animals in three western, semi-arid nature reserves in South Africa. To this end 22 animals in the Kgalagadi Transfrontier Park, 10 in the West Coast National Park and 16 in the Karoo National Park were examined. Fourteen tick species were recovered, of which Hyalomma truncatum, Rhipicephalus exophthalmos and Rhipicephalus glabroscutatum were each present in two reserves and the remainder only in one. The distributions of two of the 14 tick species recovered, namely Rhipicephalus capensis and Rhipicephalus neumanni, are virtually confined to the western semi-arid regions of southern Africa. Hyalomma truncatum, $R$. capensis and $R$. glabroscutatum were the most numerous of the ticks recovered, and eland, Taurotragus oryx, were the most heavily infested with the former two species and gemsbok, Oryx gazella, and mountain reedbuck, Redunca fulvorufula, with R. glabroscutatum.
\end{abstract}

Keywords: Geographic distribution, hosts, ixodid ticks, semi-arid nature reserves, wildlife

In addition to the Kruger National Park, which is approximately 2 million ha in size, there are numerous smaller national and provincial nature reserves in South Africa. Besides the mammals, birds, reptiles, fish, arthropods and vegetation that are protected within these reserves the parasites of the various biota are coincidentally conserved with their hosts. The larger reserves are not only important from the conservation aspect, but also because of the opportunity they afford for studies in an environment in

* Author to whom correspondence is to be directed. E-mail: ivan.horak@up.ac.za

1 Department of Veterinary Tropical Diseases, Faculty of Veterinary Science, University of Pretoria, Onderstepoort, 0110 South Africa

2 Department of Veterinary Tropical Diseases, Faculty of Veterinary Science, University of Pretoria, Onderstepoort, 0110 South Africa, and Division of Parasitology, ARC-Onderstepoort Veterinary Institute, Onderstepoort, 0110 South Africa

Accepted for publication 15 September 2006-Editor which there has been minimal human disturbance or pesticide usage.

During the past 80 years several inventories of the arthropod and helminth parasites infesting wildlife in South Africa have been published. Bedford (1932, 1936) and Haeselbarth, Segerman \& Zumpt (1966) have listed the arthropods infesting domestic and wild animals, Zumpt (1961) the mites, Theiler (1962), Walker (1991) and Walker, Keirans \& Horak (2000) the ticks, Zumpt (1965) the myiasis-producing flies, Round (1968) the helminths, Ledger (1980) the lice, and Segerman (1995) the fleas.

In recent times, particular host species and nature reserves have been targeted for the collection of parasites. A number of these studies have been conducted in the Cape Province (now subdivided into the Western Cape Province, the Eastern Cape Province, and the Northern Cape Province). During these surveys animals in the Mountain Zebra National Park, the Bontebok National Park and the Addo Ele- 
phant National Park were examined (Horak, Sheppey, Knight \& Beuthin 1986; Horak, Fourie, Novellie \& Williams 1991a; Horak, Boomker, Spickett \& De Vos 1992; Knapp, Krecek, Horak \& Penzhorn 1997), as well as animals in the Andries Vosloo Kudu Reserve (Knight \& Rechav 1978; Horak, Spickett, Braack \& Williams 1991b; Horak \& Fourie 1991; Horak et al. 1992), and the Thomas Baines Nature Reserve (Horak, Potgieter, Walker, De Vos \& Boomker 1983; Petney, Horak, Howell \& Meyer 2004).

The present paper provides an inventory of the ixodid ticks collected from wildlife in three semi-arid nature reserves in the erstwhile Cape Province, two in the region now known as the Western Cape Province and one in the now named Northern Cape Province. The helminths recovered from antelopes in two of these reserves have been recorded in a separate publication (Boomker, Horak, Watermeyer \& Booyse 2000).

The Kgalagadi Transfrontier Park, that now incorporates the former Kalahari Gemsbok National Park $\left(24^{\circ} 45^{\prime}-26^{\circ} 28^{\prime} \mathrm{S}, 20^{\circ} 00^{\prime}-20^{\circ} 50^{\prime} \mathrm{E}\right)$, which lay within the borders of South Africa, is located in a semiarid region in the northern part of Northern Cape Province and extends into the neighbouring country of Botswana. The vegetation consists of a mosaic of lightly wooded grassland on the dune crests, pure grassland in shallow depressions between the dunes, and Rhigozum trichotomum shrubby grassland in deeper hollows where the underlying calcrete is close to the surface (White 1983; Acocks 1988). During October 198422 animals were examined for ticks in the central region of the former Kalahari Gemsbok National Park.

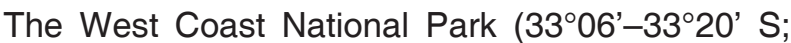
$\left.17^{\circ} 58^{\prime}-18^{\circ} 11^{\prime} \mathrm{E}\right)$, which incorporates the former Langebaan Nature Reserve is situated in a semi-arid region on the western coast of the Western Cape Province and comprises an area of 24779 ha. The vegetation is classified as Strandveld and isolated patches of Coastal Fynbos (White 1983; Acocks 1988). The park lies within the winter rainfall region of South Africa in which summers are hot and dry, and winters cold and wet. Ten animals were examined during February 1990 in this park.

The Karoo National Park (32 ${ }^{\circ} 12^{\prime}-32^{\circ} 20^{\prime}$ S; $22^{\circ} 18^{\prime}-$ $\left.22^{\circ} 39^{\prime} \mathrm{E}\right)$, comprises an area of 17706 ha near the town of Beaufort West in the north-eastern part of the Western Cape Province. It is a semi-arid region with hot summers and cold winters, and occasional snow on the higher mountain peaks. The vegetation consists of Karroid Broken Veld (Acocks 1988).
Sixteen animals were examined for ticks in this park during February 1991.

The species and numbers of animals examined are summarized in Table 1. The animals were either shot or chemically immobilized. The larger species that were shot were processed for ectoparasite recovery as described by Horak et al. (1992) for greater kudus and the smaller animals as described by Horak et al. (1986) for scrub hares. The animals that were immobilized were carefully scrutinized for ticks. The ticks collected from the processed material, or directly from the immobilized animals, were stored in $70 \%$ alcohol for later identification and counting under a stereoscopic microscope. A total of 14 ixodid tick species were recovered in this way.

Only four tick species were recovered from the 22 animals examined in the South African portion of the Kgalagadi Transfrontier Park (Table 2), and individual burdens were small. No ticks were collected from the single red hartebeest and the two springbok examined. The species collected, namely Hyalomma marginatum rufipes, Hyalomma truncatum, Rhipicephalus exophthalmos and Rhipicephalus theileri are all adapted to harsh climatic conditions (Howell, Walker \& Nevill 1978; Walker et al. 2000). The preference of $R$. exophthalmos for scrub hares and $R$. theileri for Cape ground squirrels is evident from the collections made from these animals. The latter tick is also common on yellow mongooses, Cynictis penicillata, and meercats, Suricata suricatta, which share warrens with ground squirrels (Horak, Chapparro, Beaucournu \& Louw 1999; Walker et al. 2000).

The species and numbers of ticks collected from animals in the West Coast National Park are summarized in Table 3. Six ixodid tick species were collected from the ten animals examined, and large numbers of $H$. truncatum, Rhipicephalus capensis and Rhipicephalus glabroscutatum were recovered. The distribution of $R$. capensis is virtually confined to the western winter rainfall region of the Western Cape Province, while $R$. glabroscutatum occurs not only here and in the southern Karoo, but also in the non-seasonal rainfall regions of the Western and Eastern Cape Provinces and in the Valley Bushveld of the latter province (Walker et al. 2000). The eland, probably because of their larger size, harboured considerably more adult $H$. truncatum and $R$. capensis than the gemsbok (Gallivan \& Horak 1997). Conversely the gemsbok carried larger burdens of all stages of development of the two-host ticks Rhipicephalus evertsi evertsiand $R$. glabroscutatum. All stages of the latter tick attach around the feet 
TABLE 1 Mammals examined for ticks in three western, semi-arid nature reserves in South Africa

\begin{tabular}{|l|l|l|}
\hline Host species & Scientific name & Number examined \\
\hline Red hartebeest & Alcelaphus buselaphus caama & 1 \\
Black wildebeest & Connochaetes gnou & 2 \\
Blue wildebeest & Connochaetes taurinus & 3 \\
Bontebok & Damaliscus pygargus dorcas & 2 \\
Springbok & Antidorcas marsupialis & 8 \\
Steenbok & Raphicerus campestris & 1 \\
Eland & Taurotragus oryx & 4 \\
Gemsbok & Oryx gazella & 10 \\
Grey rhebok & Pelea capreolus & 2 \\
Mountain reedbuck & Redunca fulvorufula & 2 \\
Rock hyrax & Procavia capensis & 4 \\
Cape ground squirrel & Xerus inauris & 3 \\
Scrub hare & Lepus saxatilis & 4 \\
Smith's red rock rabbit & Pronolagus rupestris & 2 \\
\hline
\end{tabular}

TABLE 2 Ixodid ticks collected from mammals in the South African part of the Kgalagadi Transfrontier Park

\begin{tabular}{|l|l|l|}
\hline Tick species & Tick life stage & Host species (total number of ticks collected) \\
\hline Hyalomma marginatum rufipes & Adult & Eland (5) \\
Hyalomma truncatum & Adult & Blue wildebeest (3), eland (39), gemsbok (62) \\
Rhipicephalus exophthalmos & Adult & Steenbok (2), gemsbok (2), scrub hares (28) \\
Rhipicephalus theileri & All & Cape ground squirrels (11) \\
\hline
\end{tabular}

TABLE 3 Ixodid ticks collected from mammals in the West Coast National Park, South Africa

\begin{tabular}{|l|l|l|}
\hline Tick species & Tick life stage & Host species (total number of ticks collected) \\
\hline Hyalomma truncatum & $\begin{array}{l}\text { Larva } \\
\text { Adult }\end{array}$ & $\begin{array}{l}\text { Rock hyrax (1) } \\
\text { Eland (609), gemsbok (131) }\end{array}$ \\
\hline Ixodes pilosus group & $\begin{array}{l}\text { Adult } \\
\text { All }\end{array}$ & $\begin{array}{l}\text { Eland (16) } \\
\text { Gemsbok (12) }\end{array}$ \\
\hline Rhipicephalus capensis & Adult & Bontebok (4), eland (1 898), gemsbok (234) \\
\hline Rhipicephalus evertsi evertsi & $\begin{array}{l}\text { Immature } \\
\text { All }\end{array}$ & $\begin{array}{l}\text { Bontebok (16), springbok (2) } \\
\text { Eland (68), gemsbok (246) }\end{array}$ \\
\hline Rhipicephalus gertrudae & Adult & Eland (6), gemsbok (2) \\
\hline Rhipicephalus glabroscutatum & $\begin{array}{l}\text { Immature } \\
\text { All }\end{array}$ & $\begin{array}{l}\text { Springbok (4) } \\
\text { Eland (25), gemsbok (7 960) }\end{array}$ \\
\hline
\end{tabular}

TABLE 4 Ixodid ticks collected from mammals in the Karoo National Park, South Africa

\begin{tabular}{|l|l|l|}
\hline Tick species & Tick life stage & Host species (total number of ticks collected) \\
\hline Amblyomma marmoreum & Larvae & Springbok (4), grey rhebok (58) \\
\hline Hyalomma glabrum & Adult & Black wildebeest (21) \\
\hline Rhipicephalus arnoldi & Immature & Rock hyrax (29), scrub hare (3), red rock rabbit (9) \\
\hline Rhipicephalus distinctus & All & Rock hyrax (129) \\
\hline Rhipicephalus exophthalmos & Adult & Springbok (22), grey rhebok (2), mountain reedbuck (13) \\
\hline Rhipicephalus glabroscutatum & $\begin{array}{l}\text { Immature } \\
\text { All }\end{array}$ & $\begin{array}{l}\text { Rock hyrax (7) } \\
\text { Grey rhebok (274), mountain reedbuck (4 916) }\end{array}$ \\
\hline Rhipicephalus neumanni & Adult & Black wildebeest (2), springbok (2), grey rhebok (2), mountain reedbuck (2) \\
\hline
\end{tabular}


and on the lower legs of their hosts (Maclvor \& Horak 1987). One of the bontebok harboured four adult $R$. capensis, and one of the springbok was infested with a small number of immature $R$. evertsi evertsi and the other with a similar number of immature $R$. glabroscutatum.

Seven ixodid tick species were recovered from the 16 animals examined in the Karoo National Park (Table 4). The dominant species was $R$. glabroscutatum and mountain reedbuck were the most heavily infested. Five fairly rarely collected tick species were recovered, namely Hyalomma glabrum, Rhipicephalus arnoldi, Rhipicephalus distinctus, R. exophthalmos and Rhipicephalus neumanni. The adults of $R$. arnoldi infest Smith's red rock rabbits and the immature stages infest these animals and other sympatric small mammals (Walker et al. 2000). All stages of development of $R$. distinctus infest rock hyraxes (Horak \& Fourie 1986; Horak et al. 1991a), and although the tick does not occur throughout the range of these small mammals its distribution is dependent on the presence of its hyrax hosts (Walker et al. 2000). Rhipicephalus neumanni is a tick of the semiarid central and western regions of South Africa and southern regions of Namibia (Walker et al. 2000). It and $R$. capensis are the only ticks of the 14 species collected that have distributions virtually confined to the south-western regions of the subcontinent.

\section{ACKNOWLEDGEMENTS}

We are most grateful to South African National Parks for placing the animals in the three reserves at our disposal, and for providing assistance and facilities to process the animals for tick recovery. The assistance of Mr M.M. Knight and Dr J.P. Louw with processing the carcasses or the immobilized animals for tick recovery is greatly appreciated. The National Research Foundation provided funds for the conduct of this project. The publication of this work has been facilitated through the Integrated Consortium on Ticks and Tick-borne Diseases (ICTTD-3), financed by the International Cooperation Program of the European Union through Coordination Action Project No. 510561.

\section{REFERENCES}

ACOCKS, J.P.H. 1988. Veld types of South Africa with accompanying veld type map, $3^{\text {rd }}$ ed. (Memoirs of the Botanical Survey of South Africa, no. 57).

BEDFORD, G.A.H. 1932. A synoptic check-list and host-list of the ectoparasites found on South African Mammalia, Aves and Reptilia. $18^{\text {th }}$ Report of the Director of Veterinary Services and Animal Industry, Union of South Africa: 223-523.
BEDFORD, G.A.H. 1936. A synoptic check-list and host-list of the ectoparasites found on South African Mammalia, Aves, and Reptilia (Supplement No. 1). Onderstepoort Journal of Veterinary Science and Animal Industry, 7:69-110.

BOOMKER, J., HORAK, I.G., WATERMEYER, R. \& BOOYSE, D.G. 2000. Parasites of South African wildlife. XVI. Helminths of some antelope species from the Eastern and Western Cape Provinces. Onderstepoort Journal of Veterinary Research, 67:31-41.

GALLIVAN, G.J. \& HORAK, I.G. 1997. Body size and habitat as determinants of tick infestations of wild ungulates in South Africa. South African Journal of Wildlife Research, 27:6370.

HAESELBARTH, E., SEGERMAN, J. \& ZUMPT, F. 1966. The arthropod parasites of vertebrates in Africa south of the Sahara (Ethiopian region). Vol. III. (Insecta excluding Phthiraptera). [Johannesburg]: South African Institute for Medical Research (Publication No. 52).

HORAK, I.G., POTGIETER, F.T., WALKER, JANE B., DE VOS, V. \& BOOMKER, J. 1983. The ixodid tick burdens of various large ruminant species in South African nature reserves. Onderstepoort Journal of Veterinary Research, 50:221-228.

HORAK, I.G. \& FOURIE, L.J. 1986. Parasites of domestic and wild animals in South Africa. XIX. Ixodid ticks and fleas on rock dassies (Procavia capensis) in the Mountain Zebra National Park. Onderstepoort Journal of Veterinary Research, 53:123-126.

HORAK, I.G., SHEPPEY, K., KNIGHT, M.M. \& BEUTHIN, C.L. 1986. Parasites of domestic and wild animals in South Africa. $\mathrm{XXI}$. Arthropod parasites of vaal ribbok, bontebok and scrub hares in the western Cape Province. Onderstepoort Journal of Veterinary Research, 53:187-197.

HORAK, I.G., FOURIE, L.J., NOVELLIE, P.A. \& WILLIAMS, E.J. 1991a. Parasites of domestic and wild animals in South Africa. XXVI. The mosaic of ixodid tick infestation on birds and mammals in the Mountain Zebra National Park. Onderstepoort Journal of Veterinary Research, 58:125-136.

HORAK, I.G., SPICKETT, A.M., BRAACK, L.E.O. \& WILLIAMS, E.J. 1991b. Parasites of domestic and wild animals in South Africa. XXVII. Ticks on helmeted guineafowls in the eastern Cape Provinceandeastern Transvaal Lowveld. Onderstepoort Journal of Veterinary Research, 58:137-143.

HORAK, I.G. \& FOURIE, L.J. 1991. Parasites of domestic and wild animals in South Africa. XXIX. Ixodid ticks on hares in the Cape Province and on hares and red rock rabbits in the Orange Free State. Onderstepoort Journal of Veterinary Research, 58:261-270.

HORAK, I.G., BOOMKER, J., SPICKETT, A.M. \& DE VOS, V. 1992. Parasites of domestic and wild animals in South Africa. XXX. Ectoparasites of kudus in the eastern Transvaal Lowveld and the eastern Cape Province. Onderstepoort Journal of Veterinary Research, 59:259-273.

HORAK, I.G., CHAPARRO, F., BEAUCOURNU, J.-C. \& LOUW, J.P. 1999. Parasites of domestic and wild animals in South Africa. XXXVI. Arthropod parasites of yellow mongooses, Cynictis penicillata (G. Cuvier, 1829). Onderstepoort Journal of Veterinary Research, 66:33-38.

HOWELL, C.J., WALKER, JANE B. \& NEVILL, E.M. 1978. Ticks, mites and insects infesting domestic animals in South Africa. Part 1. Descriptions and biology. Pretoria: Department of Agricultural Technical Services, Republic of South Africa. (Science Bulletin, no. 393).

KNAPP, S.E., KRECEK, R.C., HORAK, I.G. \& PENZHORN, B.L. 1997. Helminths and arthropods of black and white rhinocer- 
oses in southern Africa. Journal of Wildlife Diseases, 33:492502.

KNIGHT, M.M. \& RECHAV, Y. 1978. Ticks associated with kudu in the eastern Cape: preliminary report. Journal of the South African Veterinary Association, 49:343-344.

LEDGER, J.A. 1980. The arthropod parasites of vertebrates in Africa south of the Sahara. Volume IV. Phthiraptera (Insecta). [Johannesburg]: South African Institute for Medical Research (Publication no. 56).

MACIVOR, K.M. DE F. \& HORAK, I.G. 1987. Foot abscess in goats in relation to the seasonal abundance of adult Amblyomma hebraeum and adult Rhipicephalus glabroscutatum (Acari: Ixodidae). Journal of the South African Veterinary Association, 58:113-118.

PETNEY, T.N., HORAK, I.G. HOWELL, D.J. \& MEYER, S. 2004. Striped mice, Rhabdomys pumilio, and other murid rodents as hosts for immature ixodid ticks. Onderstepoort Journal of Veterinary Research, 71:313-318.

ROUND, M.C. 1968. Check list of the helminth parasites of African mammals of the orders Carnivora, Tubulidentata, Proboscidea, Hyracoidea, Artiodactyla and Perissodactyla. St. Albans: Commonwealth Bureau of Helminthology (Technical Communication, no. 38).
SEGERMAN J. 1995. Siphonaptera of southern Africa. Handbook for the identification of fleas. [Johannesburg]: South African Institute for Medical Research (Publication no. 57).

THEILER, G. 1962. The Ixodoidea parasites of vertebrates in Africa south of the Sahara (Ethiopian Region). Project S 9958. Report to the Director of Veterinary Services, Onderstepoort. Mimeographed.

WALKER, J.B. 1991. A review of the ixodid ticks (Acari, Ixodidae) occurring in southern Africa. Onderstepoort Journal of Veterinary Research, 58: 81-105.

WALKER, J.B., KEIRANS, J.E. \& HORAK, I.G. 2000. The genus Rhipicephalus (Acari, Ixodidae): a guide to the brown ticks of the World. Cambridge: Cambridge Academic Press.

WHITE, F. 1983. The vegetation of Africa. A descriptive memoir to accompany the UNESCO/AETFAT/UNSO vegetation map of Africa, + maps. Paris: UNESCO.

ZUMPT, F. 1961. The arthropod parasites of vertebrates in Africa south of the Sahara. (Ethiopian region). Vol. I (Chelicerata). [Johannesburg]: South African Institute for Medical Research (Publication no. 50).

ZUMPT, F. 1965. Myiasis in man and animals in the Old World. London: Butterworths. 